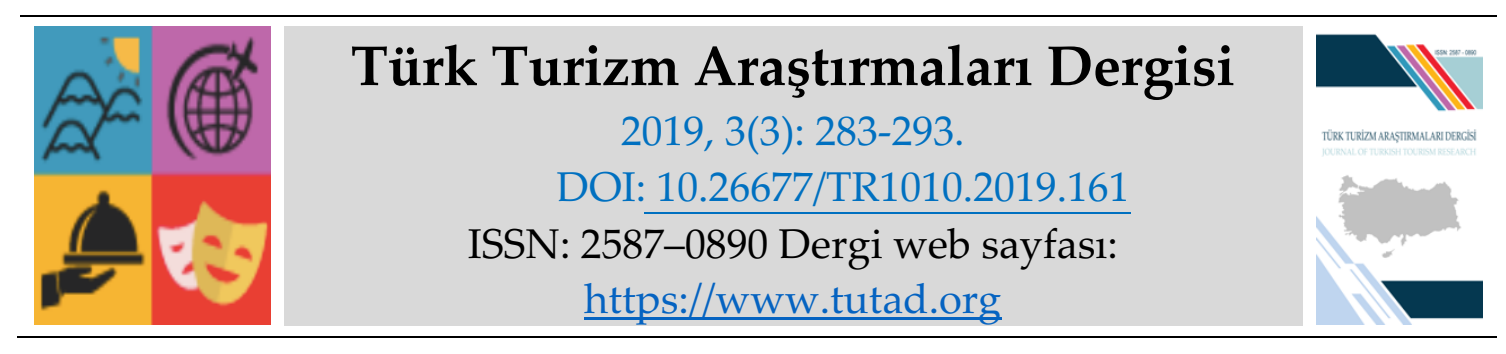

ARAȘTIRMA MAKALESI

\title{
Otel İşletmeleri İşgörenlerinin Mutluluk Algılan Üzerine Nitel Bir Çalışma
}

Dr. Ebru KEMER, Mustafa Kemal Üniversitesi, Turizm İşletmeciliği ve Otelcilik Yüksekokulu, Hatay. e-posta: kemer ebr@hotmail.com

ORCID: https://orcid.org/0000-0002-7620-6297

\section{Öz}

Bu araştırmada, Nevşehir ilindeki 5 yıldızlı otel işletmelerinde çalışan işgörenleri işyerinde mutlu ve mutsuz eden unsurları belirlemek amaçlanmıştır. Bu amaç doğrultusunda Nevşehir ilinde 2019 yılı 1-4 Mart tarihleri arasında dört adet 5 yıldızlı otel işletmesinde çalışan işgörenler ile görüşme yöntemiyle veri toplanmıştır. Araştırmada otel işletmeleri işgörenlerini iş yerinde mutlu ve mutsuz eden unsurların işyerinden ve iş dişından kaynaklanan durumlar olduğu tespit edilmiştir. Araştırma sonucunda; işgörenleri iş yerinde en çok mutlu ve mutsuz eden unsurlar maaş ve adaletli iş yeri iken iş dışında işgöreni işyerinde mutlu ve mutsuz eden en önemli unsurun ise aile ve sosyal hayat olduğu tespit edilmiştir.

Anahtar Kelimeler: Mutluluk Kavramı, İşyerinde Mutluluk, Otel İşletmeleri.

Makale Gönderme Tarihi: 11.04.2019

Makale Kabul Tarihi: 04.07.2019

\section{Önerilen Atıf:}

Kemer, E. (2019). Otel İşletmeleri İşörenlerinin Mutluluk Algıları Üzerine Nitel Bir Çalışma, Türk Turizm Araştırmaları Dergisi, 3(3): 283-293.

(C) 2019 Türk Turizm Araştırmaları Dergisi. 


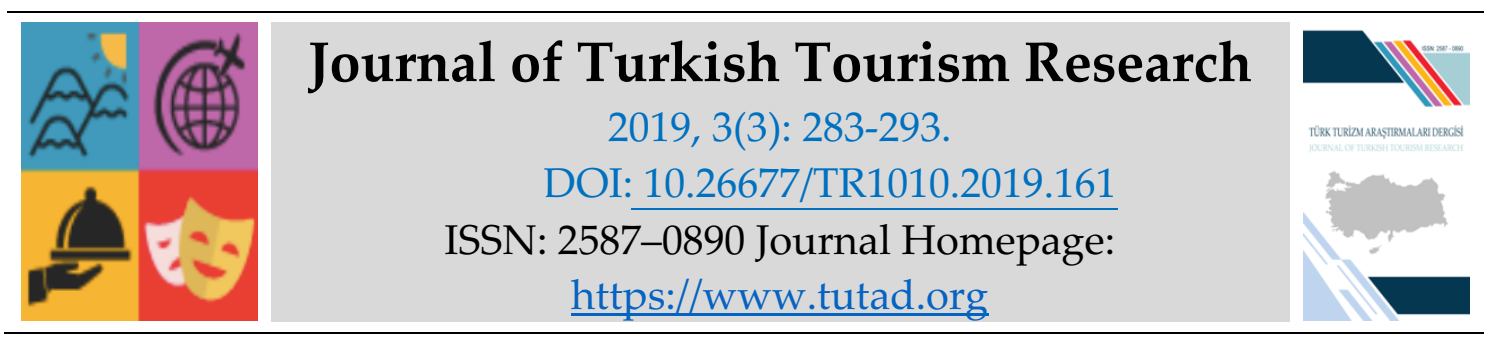

\title{
RESEARCH PAPER
}

\section{A Qualitative Study on Happiness Perceptions of Hotel Businesses Employees'}

Dr. Ebru KEMER, Mustafa Kemal University, School of Tourism and Hotel Management, Hatay. e- mail: kemer ebr@hotmail.com ORCID: https://orcid.org/0000-0002-7620-6297

\begin{abstract}
In this study, it is aimed to determine the happy and unhappy elements of the employees working in 5-star hotels in Nevşehir. For this purpose, data were collected by interviewing employees working in four 5-star hotels between the 1st of March and 4th of March, 2019 in Nevşehir. In the study, it was determined that the factors that caused the employees of the hotel enterprises happy and unhappy at the workplace were from the workplace and from the outside of the work. As a result of the research; while the most happy and unhappy employees at the workplace are salaries and fair workplaces, the most important factor that makes the employee happy and unhappy at work is family and social life.
\end{abstract}

Keywords: Happiness, Happiness in the Workplace, Hotel Management.

Received: 11.04.2019

Accepted: 04.07.2019

\section{Suggested Citation:}

Kemer, E. (2019). A Qualitative Study on Happiness Perceptions of Hotel Businesses Employees', Journal of Turkish Tourism Research, 3(3): 283-293.

(c) 2019 Türk Turizm Araştırmaları Dergisi. 


\section{Gíriş}

Otel işletmeleri amaçlarını gerçekleştirebilmek ve devamlılığını sağlayabilmek için belirli strateji, yöntem ve teknikleri kullanırlar. Otel işletmelerinin faaliyetlerini sürdürebilmesinde hayati öneme sahip olan bir unsurda müşteri memnuniyetini sağlayabilmektir. Hizmet sektörünün en önemli parçası olan otel işletmelerinde işgörenler müşteri ile iç içedir. Bu sebeple; işgörenlerin iletişim becerileri, beden dili ve davranışları müşteri memnuniyeti için önem arz etmektedir. Otel işletmeleri işgörenlerinin müşteriye güler yüzlü, anlayışlı davranması işinin bir parçasıdır. Çünkü hizmet sektöründe müşterilerin satın aldıkları ürün somut değildir ve bunun karşılı̆̆ında asık suratlı bir işgören görmek istemez. Bir otel işletmesi donanım açısından mükemmel olabilir; ama bu müşteri memnuniyetini tek başına sağlayan bir unsur değildir. Müşteriler aynı zamanda kaldıkları otellerde anı biriktirirler ve evlerine geri döndüklerinde ellerinde bir tek anıları kalır. $\mathrm{Bu}$ sebeple biriken anılar ne kadar olumlu ise müşteri o kadar memnun olmuş demektir. İşgörenin bir müşteriyi memnun etmesi için öncelikle kendisinin memnun ve mutlu olması gerektiği düşünülmektedir. İnsan sosyal bir varlıktır ve kendi içinde sorunlar yaşayan işyeriyle ilgili olumsuz duygular taşıyan birinin müşteriyi memnun etmesi beklenemez. Otel işletmeleri işgörenleri düzensiz çalışma saatleri olan, duygusal emeğin yüksek olduğu, farklı kişilikteki müşterilerle ilgilenen, aynı anda birçok işi gerçekleştirmek zorunda olan, zamanla yarışan ve aynı zamanda sürekli sakin ve güler yüzlü anlayışlı görünmek zorunda olan işgörenlerdir (Keleş ve Tuna, 2016: 377). Bu sebeple araştırmada otel işletmeleri işgörenleri tercih edilmiştir. Dolayısıyla bu araştırmada, hizmet sektörü içerisinde yer alan otel işletmelerinde çalışanların nelerden mutlu oldukları ve nelerden mutsuz oldukları sorusuna cevap aranmıştır. Çünkü işletme performansının ve verimliliğinin artmasında "beşeri unsurlar işletmeler için kritik derecede önem" arz etmektedir. (Tortop vd., 2010: 21).

\section{KAVRAMSAL ÇERÇEVE}

Mutluluk, maddi dünyada karşıllğı olmayan (Gilbert, 2008: 47) kişilerin olumlu duygular geliştirmesi, yaşamdan zevk ve haz alması gibi farklı anlamlarla açıklanmaktadır (Buettner, 2012: 27). Sırrı kişiye özel olan mutluluk (Vanderberghe, 2011: 653) "bireyin yaşamına dair olumlu düşünce ve duygularının miktarca üstünlügü bireylerin yaşamlarından aldıkları doyum ve olumlu duyguların toplamı" olarak tanımlanmaktadır (Wilson, 1967: 295). Diener, (2000: 37) ise insan hayatında mutluluğun zihinsel ve fiziksel olarak değerlendirilmesi gerektiğini ve mutluluğun kişinin hayatından genel olarak duyduğu memnuniyeti olarak ifade etmiştir. İnsan yaşamında mutluluk insanın çevresindeki kişilerin davranışlarına göre değişim göstermektedir (Veenhoven ve Dumludağ, 2015: 48). İnsanlar profesyonelde olsa iş hayatındaki duygularını özel hayatına, özel hayatındaki duyguları da iş hayatına aktarabilmektedir. Bu sebeple mutluluk pozitif duyguların ortak noktasıdır. Kişinin iş ve özel hayatındaki dengenin sağlanmasıyla işinde tutarlı şekilde çalışması, mutsuzluktan kaynaklı iş hayatında sıkıntıların olmaması özel hayatında da mutluluğu destekleyecektir (Guest, 2002: 256). Garrosa vd., (2013) çalışanların günlük mutluluğunu etkileyen değişkenleri analiz etmek amacıyla yaptıkları araştırma sonucunda iş yerindeki mutluluğun çalışanın özel hayatını, özel hayattaki mutluluğunda kişinin iş yerindeki mutluluğunu direk olarak etkilediği bulgusuna ulaşmışlardır. Ayrıca mutluluk seviyesi kişilerde değişkenlik gösterebilir. Hayatındaki değişimlerle mutluluğun seviyesi artabilir ya da azalabilir. Örneğin, kişi yeni bir iş bulduğunda önce kendisini mutlu hisseder sonra işle ilgili kaygılanmaya başlar. Balayı etkisi olarak adlandırılan bu durumda yüksek mutluluktan sonra zamanla bu mutluluğun yerini kaygı almaktadır. İş hayatında da zaman zaman bu durum görülür kişinin mutluluğunda iniş çıkışlar olur (Vanderberghe, 2011: 653). İşyerinde mutluluk, "işle ilgili iyilik hali kişinin işinde kendini zinde ve mutlu hissetmesi" olarak 
ifade edilmiştir (Keyes, 2005: 540). İşletmeler verimlilik ve performans odaklı çalışmalarından dolayı daha güçlü ve iyi olana odaklanma durumunda duygular ikinci plana atılmaktadır. İşgörenlerin sadece makine gibi görüldüğü ortamlarda çalışmaları onların zamanla fiziksel ve ruhsal olarak hastalık sebebiyle performansının düşmesine sebep olmuş ve işletmelerin bu durumda işgörenlerin olumlu ve olumsuz duygularıyla ilgilenmeye başlamasını sağlamıştır (Davies, 2016: 106-107). İşyerinde mutsuzluk kişilerin başarısını ve performansını etkileyen bir durumdur. Gallup firmasının yaptığı araştırmaya göre “işe ilgisiz işgörenler yılda ABD'de 450 ila 550 milyar dolarlık maliyet kaybı" yaşatmaktadır (Fleming, 2017: 57). Buna karşılık mutlu işgörenler, "çevresiyle daha uyumlu, doğru iletişim kurabilen, paylaşımcı, üretken ve uzlaşmacı, \%180 daha enerjik, özel hayatlarında \%180 daha mutlu ve huzurlu, işlerine ve çalıştıkları kurumlara \%108 daha bağlı, işlerini \%79 daha çok seven misyonları \%50 daha yüksek, hedeflerine \%30 daha ulaşan" kişilerdir (McKenna, 2006: 296; Pryce-Jones, 2010: 3-4).

\section{YÖNTEM}

$\mathrm{Bu}$ araştırmada nitel çalışma deseni olan, farkında olduğumuz fakat derinlemesine bilgi sahibi olmadığımız olgu bilim deseni kullanılmıştır (Yıldırım ve Şimşek, 2016: 69) Araştırmanın amacı, Nevşehir ilindeki 5 yıldızlı otel işletmelerinde çalışan işgörenleri işyerinde mutlu ve mutsuz eden unsurları belirleyebilmektir. İsyerinde mutluluk algısının bireyleri motive ederek, performanslarını arttıran bir unsur olduğu düşünülmektedir. Araştırmanın ana problemini, otel işletmeleri işgörenlerinin işyerindeki mutluluklarını sağlayan unsurlar nelerdir sorusu oluşturmaktadır. Araştırma soruları aşağıda yer almıştır.

İşyerinde mutlu olmanızı sağlayan durumlar nelerdir?

İş dışında işyerinde mutlu olmanızı sağlayan durumlar nelerdir?

İşyerinde sizi mutsuz yapan durumlar nelerdir?

İş dışında işyerinde sizi mutsuz yapan durumlar nelerdir?

\section{Çalışma Grubu}

Araştırmanın evrenini Nevşehir ilinde bulunan 5 yıldızlı otel işletmelerinde çalışan personeller oluşturmaktadır. Araştırmacı bölgede uzun zamandan beri yaşamakta, daha önce bölgedeki otellerde çalışmış, bölgeyi yakından tanımakta ve bilmektedir. Araştırmada derinlemesine bilgi toplamak için nitel araştırmada kullanılan amaçlı örnekleme türlerinden maximum çeşitlilik örneklemi kullanılmıştır. Araştırmanın örneklemini, Nevşehir ilinde faaliyet gösteren 5 yıldızlı konaklama işletmelerinde çalışan 25 işgören oluşturmaktadır.

Araştırmada maximum çeşitliliği sağlamak için dört farklı otel tercih edilmiş ve farklı departman çalışanlarıyla görüşme sağlanmaya çalışılmıştır.

\section{Veri Toplama Aracı ve Verilerin Toplanması}

$\mathrm{Bu}$ araştırmada derinlemesine bilgi edinmek ve olayları doğal ortamında olduğu gibi yansıtmak için nitel araştırma yöntemlerinde kullanılan veri toplama aracı olarak görüşme formu kullanılmıştır (Yıldırım ve Şimşek, 2016: 40-41). Görüşme formu yarı yapılandırılmış açık uçlu sorularla oluşturulmuştur. Görüşme soruları için ilgili araştırmaların yazın taraması yapılmış, akademisyen onayı alınmış, daha önceki iş tecrübelerinden yola çıkılarak oluşturulmuştur. 
Araştırma bizzat araştırmacı tarafından 1-4 Mart tarihleri arasında yürütülmüştür. Ayrıca görüşmeyi kabul eden katılımclların daha rahat cevap vermeleri ve endişe etmemeleri için katılımcılarla ilgili hiçbir kişisel veri elde edilmemiş ve veriler bilgisayar ortamında kaydedilerek alınmıştır. Araştırmada katılımcılara M1, M2, M3, ... M25 kodları verilmiş ve araştırmanın tamamında bu kodlarla yorumlama yapılmıştır.

Tablo 1. Çalışma Grubu

\begin{tabular}{llll}
\hline & & F & $\%$ \\
\hline CINSIYYT & Kadın & 15 & 60 \\
& Erkek & 10 & 40 \\
\hline DEPARTMAN & Kat Hizmetleri & 6 & 24 \\
& Mutfak & 5 & 20 \\
& Resepsiyon & 5 & 20 \\
& Yiyecek İçecek & 9 & 36 \\
\hline ÇAIŞMA SÜRESI & 1-5 yıl & 6 & 24 \\
& 5-10 yıl & 9 & 36 \\
& 10 yıl ve üzeri & 10 & 40 \\
\hline
\end{tabular}

\section{Verilerin Analizi}

$\mathrm{Bu}$ araştırmada verilerin toplanmasında, verilerin analiz ve yorumlanmasında verilerin gerçeği yansıtması için; yüz yüze görüşmeler yapılmış ve doğrudan alıntılar yapılarak araştırmanın geçerliliği sağlanmaya çalışılmıştır. Çalışmaya konu olan Nevşehir ili araştırmacının ikamet ettiği, birçok turizmciyle iç içe yaşadığı ve daha önce otel işletmelerinde çalıştığı bir ildir. Araştırmacının elde ettiği deneyim ve gözlemler verilere eklenerek verilerin bilgiye dönüşmesi sürecinde katkı sağlamıştır. Bu deneyim ve kazanımların dahil edilmesi araştırmada daha anlamlı sonuçlar elde edilmesini ortaya çıkarmıştır. Bu hususlar araştırmanın geçerlilik ve güvenilirliğine ilişkin kanıtlardır. Görüşmelerden elde edilen verileri destekler nitelikteki gözlemlerin gerçeği yakından temsil etmesi sonuçların geçerliliğini arttırmaktadır. Ayrıca elde edilen veriler görüşme, gözlem ve kişisel deneyimlerinde katkısıyla veri çeşitlenmesi sağlanmıştır. Bu araştırmada nitel araştırmada kullanılan "içerik ve betimsel analiz" yöntemleri uygulanmıştır. $\mathrm{Bu}$ doğrultuda içerik analizi dört aşamadan oluşmaktadır. 1. Verilerin kodlanması, 2. Kodlanan verilerin temalarının belirlenmesi, 3. Kodların ve temaların düzenlenmesi, 4. Bulguların tanımlanması ve yorumlanması (Yıldırım ve Şimşek, 2016: 238). Analiz sırasında otel işletmeleri çalışanlarının verdiği ifadelerin benzerliklerine göre gruplamalar yapılmış ve elde edilen veriler frekans olarak Tablo 1 'de verilmiştir. Ayrıca elde edilen verileri "çarpıcı şekilde yansıtmak amacıyla sık sık doğrudan alıntıların kullanıldığı ve elde edilen sonuçların neden sonuç ilişkisi çerçevesinde yorumlandığı" betimsel analiz tekniği kullanılmıştır (Ylldırım ve Şimşek, 2016: 238). 


\section{BULGULAR}

Görüşmelerden elde edilen verilerle yapılan analizlerde işgörenlerde mutluluğun ve mutsuzluğun "işyerinde ve iş dışından" etkilendiği tespit edilmiştir. Veriler aşağıda sunulmaktadır.

Tablo 2. İşgörenleri İşyerinde Mutlu Eden Durumlar

\begin{tabular}{|c|c|c|}
\hline & İşyerinde mutlu olmanızı sağlayan durumlar & $\mathbf{F}$ \\
\hline 1 & $\begin{array}{l}\text { Maaş } \\
\text { (M1,M2,M3,M4,M5,M6,M7,M8,M10,M11,M13,M15,M17,M18,M19,M20,M21,M22,M } \\
\text { 23,M24,M25) }\end{array}$ & 21 \\
\hline 2 & $\begin{array}{l}\text { Adalet } \\
\text { (M1,M2,M4,M5,M6,M7,M8,M10,M11,M13,M15,M17,M19,M20,M21,M22,M23,M24) }\end{array}$ & 18 \\
\hline 3 & $\begin{array}{lll}\begin{array}{l}\text { Personele } \\
\text { (M3,M4,M5,M6,M8,M10,M13,M15,M17,M18,M21) }\end{array} & \text { Çalışma } & \text { Ortamı } \\
\end{array}$ & 11 \\
\hline 4 & Çalışma Arkadaşları (M1,M2,M7,M11,M13,M15,M17,M19,M23, M24,M25) & 11 \\
\hline 5 & Takdir Edilme (M3,M5,M9,M12,M14, M16,M19,M23, M24,M25) & 10 \\
\hline 6 & Önemli Hissetme (M4,M5,M9,M12,M14, M16,M19,M21,M25) & 9 \\
\hline 7 & Fikirleri İletebilme (M3,M5,M9,M12,M14, M16,M25) & 7 \\
\hline 8 & Sevilme (M1,M2,M7,M11,M13,M15,M17) & 7 \\
\hline 9 & Başarı (M3,M5,M9,M12) & 4 \\
\hline
\end{tabular}

Otel işletmeleri çalışanlarının işyerinde mutluluklarını etkileyen kodlanmış 9 adet mutluluk kaynağı olduğu görülmektedir. Frekansı yüksek olan mutluluk kaynağı maaş, eşitlik, çalışma ortamı, çalışma arkadaşları, önemli hissetme ve takdir edilmenin işyerindeki mutluluğunu etkileyen unsurlar olduğu görülmektedir. İşörenlerin işyerindeki mutluluklarına ilişkin bazı ifadeler aşağıdaki gibidir. M5 “Günümüz şartlarında tabi ki işyerinde aldı̆̆ımız ücret çok önemli ama bunun yanında herkesle eşit olmak isterim, personele sağlanan imkanların daha iyi olması, iş arkadaşlarım beni mutlu eder. Önemli olmak ve takdir edilmek başarll olmak beni mutlu eder." M12 "Ben bu sektör için en iyi okullara gittim ve çok çaba harcadım bu sebeple işyerinde başarll olmak beni ve ailemi mutlu edecek en önemli unsur. Ayrıca yaptıklarımın görülmesini isterim fikirlerimi sunabileceğim bir ortam kendimi değerli hissettiğim takdir edildiğim bir işyeri beni çok mutlu edecektir." 
Tablo 3. İşgörenleri İş Dışında iş Yerinde Mutlu Eden Durumlar

\begin{tabular}{|l|l|l|}
\hline & İş dışında işyerinde mutlu olmanızı sağlayan durumlar & F \\
\hline $\mathbf{1}$ & $\begin{array}{l}\text { Aile ve Sosyal Hayat (M1,M2,M4,M5,M6,M7,M8,M9,M10,M11,M12, } \\
\text { M14,M15,M16,M17,M18,M19,M20,M21,M22,M23) }\end{array}$ & $\mathbf{2 1}$ \\
\hline $\mathbf{2}$ & $\begin{array}{l}\text { Maaş (M1,M2,M3,M4,M5,M6,M7,M8,M10,M13,M15,M17,M19,M20,M22,M23, } \\
\text { M24,M25) }\end{array}$ & $\mathbf{1 8}$ \\
\hline $\mathbf{3}$ & Düzenli Yaşam (M1,M5,M6,M8,M9,M11,M14, M16,M18,M19,M20,) & $\mathbf{1 1}$ \\
\hline $\mathbf{4}$ & Kendime Zaman Ayırabilme (M1, M4, M6, M9, M11,M12, M14, M16, ,M19, ,M21,) & $\mathbf{1 0}$ \\
\hline $\mathbf{5}$ & Emeklerimin karşılığını alabilme (M3,M10,M13,M24,M25) & $\mathbf{5}$ \\
\hline $\mathbf{6}$ & İşten ayrılma stresinin olmaması (M1,M5,M19,M25) & $\mathbf{4}$ \\
\hline
\end{tabular}

Otel işletmeleri işgörenlerinin dışsal faktörlerin işyerindeki mutluluklarını etkileyen kodlanmış 6 adet mutluluk kaynağı olduğu tespit edilmiştir. Aile hayatı ve maaşın işyerindeki mutluluğu etkileyen en önemli unsurlar olduğu görülmektedir. Aile hayatını önemini M1 şu şekilde belirtmiştir. M1 "Ailem çok önemli ben evli değilim fakat ailemde yaşanan ufacık bir sıkıntı beni etkiler. Çalışırken aklım başımda olmaz. Örneğin kardeşim trafik kazası geçirdi hastanedeydi hayati tehlikesi yoktu fakat kendimi oradan alamadım. Resepsiyonda çalıştığım için hep güler yüzlü olmak zorundayım fakat gergin ve depresiftim. Zor atlattım bu durumu. Birde maaş, işten ayrilma veya izin kullanamama gibi durumlar insanı ister istemez mutsuz ediyor. Maaşınız az olduğu zaman dışarda da mutlu olamıyorsunuz çünkü sosyal yaşam için para gerekiyor. Turizm kötü gittiği zaman işten ayrılma durumumuz bunlar hep mutsuzluk yaratıyor. M5 “3 sene önce yaşadığımız turizmde sıkıntıların olması ve işten ayrılma durumu dışardaki bütün hayatını alt üst ediyor dışarıdaki yaşanan olumsuzluklar maalesef iş yerine de getiriyoruz çünkü insanız.

Otel işletmeleri işgörenlerinin işyerinde mutsuz olmalarına sebep olan kodlanmış 10 adet mutsuzluk kaynağı olduğu görülmektedir. Otel işletmeleri işgörenleri işyerinde en çok mutsuz olmalarına sebep olan durumları maaş adaletsizlik çalışma ortamı, çalışma arkadaşları ve takdir edilme olarak belirtmişlerdir. M15 "İsyerinde de beni mutsuz eden en önemli sebep maaş olurdu, herkese aynı davranılmaması, çalışılan ortamının pis dağınık ve düzensiz olması, iş arkadaşlarımla anlaşamamak onlarla iletişim sıkıntısı yaşamak ve takdir edilememe beni mutsuz eder." İşgörenler başarısızlık, görev tanımlarının belirsiz olması, izinlerini istedikleri zamanda kullanamama unsurlarının da işyerinde mutsuzluk yarattı̆̆ını belirtmiştir. M21 Beni mutsuz eden hakkımı alamamak eşit olmayan bir çalışma ortami, değer görmeme, önemsiz olma ve belki de biraz daha özgürlük istiyorum mesela izinlerimi ben istediğim zamanda kullanmak istiyorum işler az olduğunda düşük sezonda değil. Ayrıca değer görmediğimizi anlamak hiçte zor değil: personele verilen yemek bile bir işletmenin bize ne kadar değer verdiğini gösterir. 
Tablo 4. İşgörenleri İş Yerinde Mutsuz Eden Durumlar

\begin{tabular}{|l|l|l|}
\hline & İşyerinde mutsuzluk yaratan durumlar & F \\
\hline $\mathbf{1}$ & $\begin{array}{l}\text { Maaş } \\
\text { (M1,M3,M4,M5,M7,M8,M9,M10,M12,M14,M15,M17,M18,M19,M20,M22,M23,M25) }\end{array}$ & $\mathbf{1 8}$ \\
\hline $\mathbf{2}$ & $\begin{array}{l}\text { Adalet } \\
\text { (M2,M3,M4,M5,M7,M8,M9,M11,M12,M14,M15,M17,M18,M19,M21,M22,M23,M24) }\end{array}$ & $\mathbf{1 8}$ \\
\hline $\mathbf{3}$ & Çalışma Ortamı (M1,M3,M4, M6,M7,M9,M10,M12, M15, M18,M19,M20,M22, M25) & $\mathbf{1 4}$ \\
\hline $\mathbf{4}$ & Çalısma arkadaşları (M1,M2,M5,M6,M7,M9,M12,M15,M18,M19,M20,M22, M24) & $\mathbf{1 3}$ \\
\hline $\mathbf{5}$ & Takdir edilmeme (M2,M3,M5,M6,M8,M9,M11,M15,M18,M19,M21,M22, M24) & $\mathbf{1 3}$ \\
\hline $\mathbf{6}$ & Fikirleri İletememe (M2, M6, M9, M15, M19,M21, M24) & $\mathbf{7}$ \\
\hline $\mathbf{7}$ & Başarısizlık (M2, M16,M25) & $\mathbf{3}$ \\
\hline $\mathbf{8}$ & Önemsiz hissetme (M2,M11,M21) & $\mathbf{3}$ \\
\hline $\mathbf{9}$ & Eksik Görev Tanım1 (M6) & $\mathbf{1}$ \\
\hline $\mathbf{1 0}$ & İstediğim zamanlarda iznimi kullanabilmem (M21) & $\mathbf{1}$ \\
\hline
\end{tabular}

Tablo 5. İşgörenleri İş Dışında iş Yerinde Mutsuz Eden Durumlar

\begin{tabular}{|c|c|c|}
\hline & İş dışında işyerindeki mutsuzluğa sebep olan durumlar & $\mathbf{F}$ \\
\hline 1 & $\begin{array}{l}\begin{array}{l}\text { Ailede } \\
\text { Sosyal }\end{array} \\
(\mathrm{M} 1, \mathrm{M} 3, \mathrm{M} 5, \mathrm{M} 6, \mathrm{M} 8, \mathrm{M} 9, \mathrm{M} 11, \mathrm{M} 12, \mathrm{M} 13, \mathrm{M} 14, \mathrm{M} 15, \mathrm{M} 18, \mathrm{M} 19, \mathrm{M} 21, \mathrm{M} 23, \mathrm{M} 25)\end{array}$ & 16 \\
\hline 2 & Maaş (M2,M5,M6,M9,M10,M11,M15,M18,M21,M22, M24) & 11 \\
\hline 3 & İşimi sevmeme (M3,M4,M7,M8,M9,M16,M17,M19,M20,M22, M24) & 11 \\
\hline
\end{tabular}

Otel işletmeleri işgörenlerinin dışsal faktörlerin işyerindeki mutsuz olmalarına sebep olan durumları maaş ailede gerginlik, işimi sevmeme unsurlarıdır. M9 "Bir ailem ve çocuklarım var bu yüzden hem işyerinde hem iş dışında maaşımın az olması beni mutsuz eder çünkü sosyal hayatımda para sıkıntısı yaşarsam bu ailemde sorun yaşamaya sebep olur ve iş yerine gittiğimde bu durum aklımdan çıkmaz orda da mutsuz olurum. Her ikisi de birbirini etkileyen durumlar. Ayrıca benim öyle bir lüksüm yok fakat yaptığım işi sevmemek beni çok rahatsız ederdi. Turizm gibi zor bir sektör sevilmeden yapılacak iş değil çok zor gerçekten. M7 “ Ĕ̆er işimi sevmeseydim çok mutsuz olurdum. Çünkü biz robot değiliz ve insanlara hizmet etmek zorundayız bu herkesin yapabileceği bir iş değil. Birde insanın gerçekten nefret ettiği zamanlar oluyor ama zaman içinde duygularını kontrol etmeyi öğreniyorsun." 
Araştırma bulgularına göre işgörenlerin işyerinde mutluluğunu sağlayan unsurların başında gelir, sosyal çevre, iş çevresi, aile ve iş arkadaşları gibi sosyal ve çevresel faktörler gelmektedir. Literatür incelendiğinde mutluluk kavramı; iş tatmini (Kara, 2010, verimlilik (Taris ve Schreurs, 2009), örgütsel bağlılık (Dehaghi, 2012) ve örgütsel vatandaşlık (Yurcu, 2014) kavramları ile ilişkilendirilmiştir. Ayrıca gelir, boş zaman algısı, çevresel faktörler, arkadaşlar gibi faktörlerin bireylerin mutluluğunda etkili olduğu tespit edilmiştir (Haller ve Hadler, 2006: 203; Bailey ve Fernando, 2012: 141).

\section{SONUÇ VE TARTIŞMA}

İnsanlar hayatta kalabilmek, para kazanabilmek, sorumluklarını yerine getirebilmek için zamanlarının büyük çoğunluğunu işyerinde geçirmektedir. İşyerinde veya iş dışında yaşanan olumlu ve olumsuz durumlar işgörenleri işyerinde etkilemektedir. İşgörenin mutluluğu işyerindeki performans ve verimliliği etkileyen unsurlardan bir tanesidir. Otel işletmeleri için hayati öneme sahip olan müşteri memnuniyetini sağlamada otel işletmeleri işgörenleri en önemli araçtır. İşgörenlerin mutlu olması, işlerini yaparken hem daha etkin çalışmalarına hem de müşterilerin daha memnun olmasına katkı sağlayacağı düşünülmektedir. Dolayısıyla bu araştırmada "Otel işletmelerinde çalışanların mutluluklarını sağlayan unsurlar nelerdir?" ana problemine cevap aranmıştır. Araştırma sonucunda araştırma sorularından biri olan otel işletmeleri işgörenlerini işyerinde mutlu eden durumların maaş, adaletli ortam, çalışma ortamı, çalışma arkadaşları, takdir edilme, önemli hissetme fikirleri iletebilme, sevilme, başarı olarak 9 adet durum tespit edilmiştir. Yirmi bir kişi en önemli unsurun maaş olduğunu söylemiştir. Otel işletmeleri işgörenlerini işyerinde mutsuz eden durumlara baktığımızda ise maaş, adaletsizlik, çalışma ortamı, çalışma arkadaşları, takdir edilmeme, iletişim sorunu, başarısızlık, önemsiz hissetme eksik görev tanımı, istediğim zamanlarda iznimi kullanamama cevaplarını vermişlerdir. Yine işyerindeki en önemli mutsuzluk sebebinin maaş ve adaletsiz uygulamalar olduğu görülmektedir.

Otel işletmeleri işgörenlerinin iş dışında işyerindeki mutluluğunu nelerin etkilediğine baktığımızda ise aile ve sosyal hayat, maaş, düzenli yaşam, kendine zaman ayırabilme, hak ettiğini alabilme ve işten ayrılma stresinin olmaması durumları tespit edilmiştir. Aile hayatının işgörenler için ne kadar önemli olduğu görülmektedir. Ayrıca maaşın işgörenlerin iş dışında da mutlu olması ve bu mutluluğu işyerine taşıyabilmesi için önemli olduğu görülmektedir.

Otel işletmeleri işgörenlerinin iş dışında işyerinde mutsuz olmasına sebep olan durumlar ise ailede sosyal hayatta gerginlik, maaş ve işimi sevmeme cevapları verilmiştir. İşgörenlerin ailede yaşadığı sorunlar veya sosyal hayatında yaşadığı sıkıntıların işgörenleri işyerinde en çok mutsuz eden durumlar olduğu görülmektedir.

Otel işletmeleri işgörenlerinin mutlu olmalarında en önemli unsurun maaş olduğu görülmektedir. Maaş insanın önce kendine sonra ailesine yetebilme göstergesi ve sorumluluklarını yerine getirebilmesini sağlayan önemli bir unsurdur. Çalışan ailesinin ve kendisinin sorumluluklarını yerine getiremediği zaman ailede veya sosyal hayatta gerginlikler başlar. Yani aslında maaş ve ailede gerginliğin birbiriyle ilişkili olduğu ortaya çıkmıştır. Ayrıca adaletli ortam, personele ayrilan zaman ve mekanlar, sevilme ve takdir edilme gibi unsurların işgörenler açısından maaş kadar önemli olduğu görülmektedir. Kötü soyunma odalarına sahip, iki günlük yemekleri yediği bir yemekhanede zaman geçiren personelin mutlu olması ve en iyi hizmeti sunması beklenemez. Dolayısıyla işgörenlerin, adaletli bir işyerinde değer görmek istedikleri, sevilip takdir edildikleri ve bu değerin onları mutlu ettiği sonucuna ulaşılabilir. Mutlu işgören işini daha severek yapacak ve mutluluğu hem çalışma arkadaşlarına yansıyacak hem de müşterilerin memnuniyetini arttıracaktır. Otel işletmeleri yönetimlerinin mutlu işgören profili 
oluşturabilmesi için adaletli bir ortamda herkesin maddi manevi hak ettiğini sağlayabileceği iş ortamları yaratması gerekmektedir. Tabi ki günümüz şartlarında maddi açıdan işletmelerde sıkıntı yaşamaktadır fakat bu durum işgörenlerin takdir edilmesini sevilmesini veya çalışma ortamlarının daha insani şartlarda olmasını engellemez. Ayrıca iş tanımlarının net olarak yapılması hem otel işletmeleri işgörenleri arasında daha iyi iletişimin oluşmasına hem de iş arkadaşlarıyla daha koordineli çalışmasına olanak sağlayabilir.

\section{KAYNAKÇA}

Bailey, Andrew W. and Fernando, Irene K. (2012). Routine and Project-Based Leisure, Happiness and Meaning in Life, Journal of Leisure Research, 44 (2): 139-154.

Buettner, D. (2012). Mutluluk. İstanbul: Butik Yayıncılık.

Davies, W. (2016). The Happiness Industry. Verso, London. www.researchgate.net/publication/283828736_The_happiness_industry_How_government_and _big_business_sold_us_well-being (Erişim Tarihi: 01.04.2019).

Dehaghi, M.R. (2012). Happiness as an Effective Factor in Organizational Commitment of Managers, African Journal of Business Management, 6 (33): 9460-9468.

Diener, E. (2000). Subjective Well-being: The Science of Happiness and a Proposal for a National Index, American Psychologist, 55: 34-43.

Fleming, P. (2017). Çalışmanın Mitolojisi, İstanbul: Koç Üniversitesi Yayınları.

Garrosa, E., Carmona, L., Ladstatter, F., Blanco, L.M. and Cooper-Thomas, H.D. (2013). The Relationships Between Family-Work Interaction, Job-Related Exhaustion, Detachment, And Meaning in Life: A day-level study of emotional well-being. Revista de Psicologia del Trabajo y de las Organizaciones, 29: 169-177.

Guest, D. E. (2002). Perspectives on the Study of Work-life Balance, Social Science Information, 41 (2), 255-279.

Gilbert, D. (2008). Mutluluk Üzerine Çeşitlemeler. (Çevirenler: Şar, F. ve Hekimoğlu, G. A.) İstanbul: Optimist Yayınları.

Haller, M. and Hadler, M. (2006). How Social Relations and Structures Can Produce Happiness and Unhappiness: An International Comparative Analysis. Social Indicators Research, 75 (2):169216.

Kara, M.M. (2010). The Relation of Job Satisfaction with Happiness and Success Level, Yüksek Lisans Tezi, Marmara Üniversitesi Sosyal Bilimler Enstitüsü, İstanbul.

Keyes, C. L. M. (2005). Mental Illness and /or Mental Health? Investigating Axioms of the Complete State Model of Health, Journal of Consulting Clinical Psychology, 3: 539-548.

McKenna, E. (2006). Business Psychology and Organizational Behaviour. Fourth Edition, Psychology Press, New York. http://library1.ue-varna.bg:7480/ft/KNG/R0032391.PDF, (Erişim Tarihi: 01.04.2019).

Pryce-Jones, J. (2010). Happiness at Work. Wiley-BlackWell Publication, United Kingdom, https://leseprobe.buch.de/images-adb/95/14/95147515-3a2d-49c2-9f29-91b5b81c8fcb.pdf, (Erişim Tarihi: 01.04.2019). 
Taris, Toon W. and Schreurs, Paul J.G. (2009). Well-Being and Organizational Performance: An Organizational-Level Test of the Happy-Productive Worker Hypothesis, Work \& Stress, 23 (2): 120-136.

Vanderberghe, C., Panaccio, A., Bentein, K., Mignonac, K. and Roussel, P. (2011). Assessing Longitudinal Change of and Dynamic Relationships Among Role Stressors, Job Attitudes, Turnover Intention and Well-being in Neophyte Newcomers, Journal of Organizational Behavior, 32: 652-671.

Veenhoven, R., Dumludağ, D. (2015). İktisat ve Mutluluk, İktisat ve Toplum Dergisi, 58: 46-51.

Wilson, W. R. (1967). Correlates of Avowed Happiness, Psychological Bulletin, 67 (4): 294- 306.

Yıldırım, A. ve Şimşek, H. (2016). Sosyal Bilimlerde Nitel Araştırma Yöntemleri. Ankara: Seçkin Yayıncilik.

Yurcu, G. (2014). Konaklama İşletmelerinde Çalışanların Örgütsel Vatandaşlık Davranışlarının İş Doyumu ve Öznel İyi Oluşlarma Etkisi, Yüksek Lisans Tezi, Adnan Menderes Üniversitesi Sosyal Bilimler Enstitüsü, Aydın. 